\section{DAPSA versus CDAPSA: Do we need to use CRP?}

\section{INTRODUCTION}

In recent years, there has been a paradigm shift towards the development of disease activity indexes that correspond to the clinical measures and also the results reported by the patients, thus capturing the total burden of the disease. ${ }^{1}$

Disease Activity Index for Psoriatic Arthritis (DAPSA) ${ }^{2}$ is an index for measuring disease activity in psoriatic arthritis (PsA) that use C-reactive protein (CRP) as activity biomarker. Recently, van Mens et $a l^{1}$ shown that the use of clinical DAPSA (cDAPSA) was similar to DAPSA using CRP. Our objective is evaluating whether CRP influences the achievement of different DAPSA disease states, and therefore we compared DAPSA with and without CRP.

\section{METHODOLOGY}

Trained rheumatology collected clinical data from 124 eligible patients, including swollen and tender joint count (SJC 66 and TJC 68 joints).

DAPSA is calculated with the number of painful joints + swollen joints + VASptGlobal $(0-10 \mathrm{~cm})+$ VASptPain $(0-10$ $\mathrm{cm})+$ protein creatinine ratio $\mathrm{mg} / \mathrm{dL}$.

For the cDAPSA, which omits CRP, thresholds between remission (REM), low disease activity (LDA), minimal disease activity (MDA) and high disease activity (HDA) were use 4, 13 and 27 for the differentiation of disease activity states based on clinical parameters only, in the other hand DAPSA (using CRP) were 4, 14 e 28.

The agreement between the tested definitions was established using $2 \times 2$ tables and percentage exact agreement and calculation of a kappa.

We also analysed, using $\chi^{2}$ test, the correlation between different disease status according to the two definitions (DAPSA LDA/REM and DAPSA MDA/HDA) and CRP $(\leq 0.5 \mathrm{mg} / \mathrm{dL}$ or $>0.5 \mathrm{mg} / \mathrm{dL}$ ) and $\mathrm{p}$ values $<0.05$ were considered significant for $\chi^{2}$ testing. Correlations between absolute number of CRP and DAPSA were determined using Spearman's correlation. All data were analysed with GraphPad Prism 6.

\section{RESULTS}

\section{Agreement between the DAPSA and cDAPSA}

The agreement between each thresholds of measures in those 77 patients was considered almost perfect with kappa: 0.840 (95\% CI: 0.742 to 0.938 ) as shown in table 1 .

\section{DAPSA activity status versus CRP, and correlation between absolute values}

Of the 50 patients who achieved DAPSA LDA/REM disease, 33 patients had CRP $\leq 0.5 \mathrm{mg} / \mathrm{dL}$ and 17 patients had CRP $>0.5 \mathrm{mg} /$

\begin{tabular}{lcccc}
\hline $\begin{array}{l}\text { Table } 1 \\
\text { status }\end{array}$ & Number of patients correlated according disease activity \\
\hline & cDAPSA REM & cDAPSA LDA & cDAPSA MDA & cDAPSA HDA \\
\hline DAPSA REM & 14 & 0 & 0 & 0 \\
\hline DAPSA LDA & 9 & 25 & 0 & 0 \\
\hline DAPSA MDA & 0 & 0 & 15 & 0 \\
\hline DAPSA HDA & 0 & 0 & 0 & 14 \\
\hline
\end{tabular}

DAPSA, Disease Activity Index for Psoriatic Arthritis; HDA, high disease activity; LDA, low disease activity; MDA, moderate disease activity.

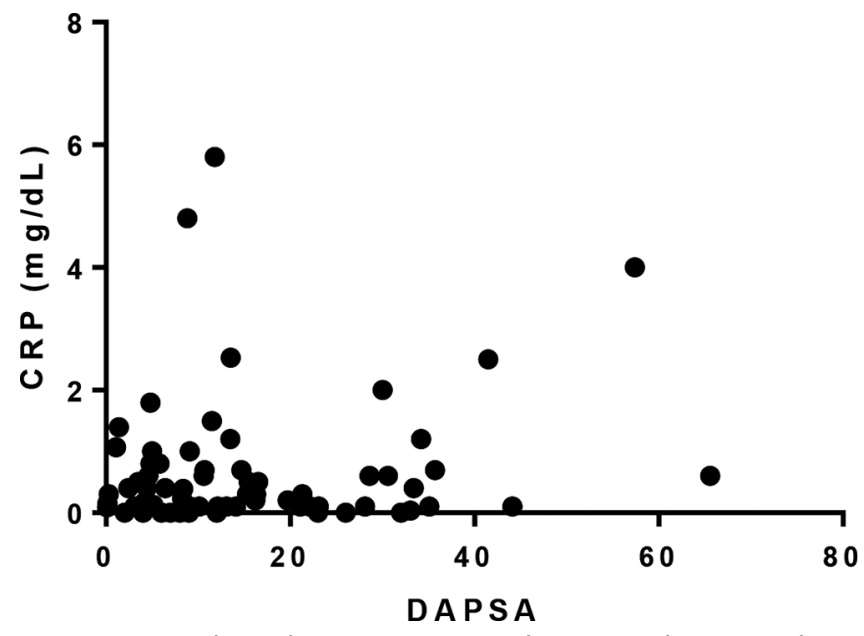

Figure 1 Correlation between DAPSA and corresponding CRP values. CRP, C-reactive protein; DAPSA, Disease Activity Index for Psoriatic Arthritis.

dL. Of the patients who maintained moderate/high activity by DAPSA, 19 had CRP $<0.5 \mathrm{mg} / \mathrm{dL}$ while only eight patients had CRP $>0.5 \mathrm{mg} / \mathrm{dL}$. There was no correlation statistically significance with $\mathrm{p}=0.89$.

When we correlated the DAPSA values (of the 77 patients that performed) with the absolute values of the CRP in $\mathrm{mg} / \mathrm{dL}$ presented, respectively, we did not find statistically significant correlation, $\mathrm{r}=0.125$ (Spearman's index), as shown in figure 1 .

\section{DISCUSSION}

The main problem in clinical routine is which one measure of disease is more appropriated. Not all measures of disease activity in PsA included an inflammatory marker in calculation. The DAPSA and Psoriatic Arthritis Disease Activity Score (PASDAS) ${ }^{3}$ include CRP, and cDAPSA and MDA $)^{4}$ measures do not.

In our population, the difficulty to perform CRP makes applicability of a clinical measure more feasible in outpatients routine, and this observation is in accordance with other studys. ${ }^{1}$ The correlation between cDAPSA and DAPSA was high, as observed in van Mens et $a l^{1}$ and therefore any of those tools could be used. As already shown in that study, ${ }^{1}$ we also demonstrated some patients with a raised CRP fulfilled remission score activity and vice versa showing that this biomarker perhaps is not the ideal to use in PsA disease targets. As we know, CRP perhaps is not the ideal inflammation marker to measure active PsA. ${ }^{15}$

The almost perfect agreement between cDAPSA and DAPSA suggest that the inclusion of CRP can be unnecessary. Besides, a target without an inflammatory marker seems to be more feasible in clinical routine.

Rafaela Silva Guimarães Gonçalves @ ( ) Lays Miranda de Almeida Martins, Henrique de Ataide Mariz, Andrea Tavares Dantas, Angela Luzia Branco Pinto Duarte

Department of Rheumatology, Clinical Hospital of Federal University, Recife, Pernambuco, Brazil

Correspondence to Dr Rafaela Silva Guimarães Gonçalves, Hospital das Clinicas de pernambuco, Recife 50670-901,Brazil; rafa_sgg@hotmail.com

Acknowledgements We thank our patients.

Contributors All contributors meet criteria for authorship.

Funding The authors have not declared a specific grant for this research from any funding agency in the public, commercial or not-for-profit sectors.

Competing interests None declared.

Patient consent for publication Not required. 
Ethics approval This study was reviewed and approved by the local medical research ethics committee of Clinical Hospital (Federal University of Pernambuco/ EBSERH; CAAE 08028119.7.0000.8807.

Provenance and peer review Not commissioned; internally peer reviewed. (C) Author(s) (or their employer(s)) 2020. No commercial re-use. See rights and permissions. Published by BMJ.

\section{(A) Check for updates}

To cite Gonçalves RSG, de Almeida Martins LM, de Ataide Mariz H, et al. Ann Rheum Dis 2020;79:e142.

Received 28 June 2019

Accepted 4 July 2019

Published Online First 22 July 2019

\section{Linked}

http://dx.doi.org/10.1136/annrheumdis-2019-215990

Ann Rheum Dis 2020;79:e142. doi:10.1136/annrheumdis-2019-215960

\section{ORCID iD}

Rafaela Silva Guimarães Gonçalves http://orcid.org/0000-0001-9014-6529

\section{REFERENCES}

1 van Mens LJJ, van de Sande MGH, van Kuijk AWR, et al. Ideal target for psoriatic arthritis? comparison of remission and low disease activity states in a real-life cohort. Ann Rheum Dis 2018:77:251-7.

2 Schoels MM, Aletaha D, Alasti F, et al. Disease activity in psoriatic arthritis (PSA): defining remission and treatment success using the DAPSA score. Ann Rheum Dis 2016;75:811-8

3 Helliwell PS, Waxman R. Modification of the psoriatic arthritis disease activity score (PASDAS). Ann Rheum Dis 2018;77:467-8.

4 Coates LC, Fransen J, Helliwell PS. Defining minimal disease activity in psoriatic arthritis: a proposed objective target for treatment. Ann Rheum Dis 2010;69:48-53.

5 Bellan M, Bor S, Gibbin A, et al. Inflammatory markers predict insulin sensitivity in active rheumatoid arthritis but not in psoriatic arthritis. Reumatismo 2018;70:232-40. 